\title{
The Effect of Ketone Bodies on Renal Ammoniogenesis
}

\author{
Guy Lemieux, Patrick Vinay, Pierre Robitallle, Gérard E. Plante, \\ Yolande Lussier, and Pierre Martin \\ From the Renal Laboratory, Hôtel-Dieu Hospital and the Department of \\ Medicine, University of Montreal School of Medicine, \\ Montreal, Quebec, Canada
}

A в S T R A C T Infusion of ketone bodies to ammonium chloride-loaded acidotic dogs was found to induce significant reduction in urinary excretion of ammonia. This effect could not be attributed to urinary $\mathrm{pH}$ variations. Total ammonia production by the left kidney was measured in 25 animals infused during $90 \mathrm{~min}$ with the sodium salt of D,L- $\beta$-hydroxybutyric acid adjusted to $\mathrm{pH} 6.0$ or 4.2 . Ketonemia averaged $4.5 \mathrm{~mm} /$ liter. In all experiments the ammonia content of both urine and renal venous blood fell markedly so that ammoniogenesis was depressed by $60 \%$ or more within $60 \mathrm{~min}$ after the onset of infusion. Administration of equimolar quantities of sodium acetoacetate adjusted to $\mathrm{pH} 6.0$ resulted in a $50 \%$ decrease in renal ammonia production. Infusion of ketone bodies adjusted to $\mathrm{pH}$ 6.0 is usually accompanied by a small increase in extracellular bicarbonate ( $3.7 \mathrm{~mm} / \mathrm{liter})$. However infusion of $\mathrm{D}, \mathrm{L}$-sodium lactate or sodium bicarbonate in amounts sufficient to induce a similar rise in plasma bicarbonate resulted in only a slight decrement in ammonia production (15\%). The continuous infusion of $5 \%$ mannitol alone during 90-150 min failed to influence renal ammoniogenesis. Infusion of pure sodium-free $\beta$-hydroxybutyric acid prepared by ion exchange $(\mathrm{pH} 2.2)$ resulted in a $50 \%$ decrease in renal ammoniogenesis in spite of the fact that both urinary $\mathrm{pH}$ and plasma bicarbonate fell significantly. During all experiments where ketones were infused, the renal extraction of glutamine became

This work was presented in part at the 4th International Congress of Nephrology, Stockholm, Sweden, June 1969.

Dr. Vinay is a Research Fellow of the Medical Research Council of Canada.

Dr. Robitaille and Dr. Plante are former Research Fellows of the Canadian Arthritis and Rheumatism Society. Miss Lussier and Mr. Martin are medical students who were supported by Research Fellowships from the Ministry of Health of the Province of Quebec and the Canadian Arthritis and Rheumatism Society.

Received for publication 8 June 1970 and in revised form 3 March 1971. negligible as the renal glutamine arteriovenous difference was abolished. Renal hemodynamics did not vary significantly. Infusion of $\beta$-hydroxybutyrate into the left renal artery resulted in a rapid decrease in ammoniogenesis by the perfused kidney. The present study indicates that ketone bodies exert their inhibitory influence within the renal tubular cell. Since their effect is independent of urinary or systemic acid-base changes, it is suggested that they depress renal ammoniogenesis by preventing the transformation of glutamine and glutamate into $\alpha$-ketoglutarate in the mitochondria of the renal tubular cell.

\section{INTRODUCTION}

It is well-known that diabetic subjects suffering from ketoacidosis excrete large amounts of ammonia in their urine (1). The major stimulus for increased renal production and excretion of ammonia is believed to be the severe metabolic acidosis caused by progressive accumulation of ketones in the body fluids (2). A similar mechanism is thought to be operative during prolonged fasting in obese human subjects (3). It is not known however, whether ketone bodies influence renal ammoniogenesis solely by their acidifying effect or by some other mechanism. During studies designed to investigate the effect of ketone bodies on uric excretion in the dog, a significant decrease in urinary ammonia excretion was persistently noted during ketone infusion. This paradoxical observation prompted the undertaking of the present study. The data reveal that ketone bodies markedly depress renal ammoniogenesis in the dog. This effect does not appear to be related to changes in urinary $\mathrm{pH}$ or variations in systemic acid-base status. A1though the precise nature of this inhibitory effect remains to be determined, the depression in renal ammonia production observed in the present study is associated with striking decrease in the renal extraction of glutamine. 


\section{METHODS}

Experiments were performed on 93 female mongrel dogs weighing between 14 and $21 \mathrm{~kg}$. During the 3 days which preceded the experiment each animal was given ammonium chloride $7 \mathrm{~g}$ per day by stomach tube in two equal doses (9.00 a.m. and 3.00 p.m.). During this period, the animals were fed dog Purina Chow and had free access to water. Food was withheld during $20 \mathrm{hr}$ before anesthesia but free water intake was allowed. The animals were anesthetized with sodium pentobarbital and intubated. The endotracheal tube fitted with an inflatable balloon was connected to a volume and rate adjustable respiration pump (Harvard Apparatus Co, Millis, Mass.). Heparinized blood samples were drawn anaerobically from the femoral artery. All solutions were delivered to a femoral vein with a Bowman type infusion pump at the rate of $5.6 \mathrm{ml} / \mathrm{min}$. During the control periods, the animals were infused with $5 \%$ mannitol containing appropriate amounts of creatinine and paraaminohippurate. After adequate and stable urine flow had been achieved, three $10-\mathrm{min}$ collections of urine were taken as controls. In 25 animals, urinary excretion of ammonia was studied following infusion of $\mathrm{D}, \mathrm{L}-\boldsymbol{\beta}$-hydroxybutyric acid. A priming dose ( $40 \mathrm{~mm}$ ) of $\mathrm{D}, \mathrm{L}-\boldsymbol{\beta}$-hydroxybutyric acid as the sodium salt

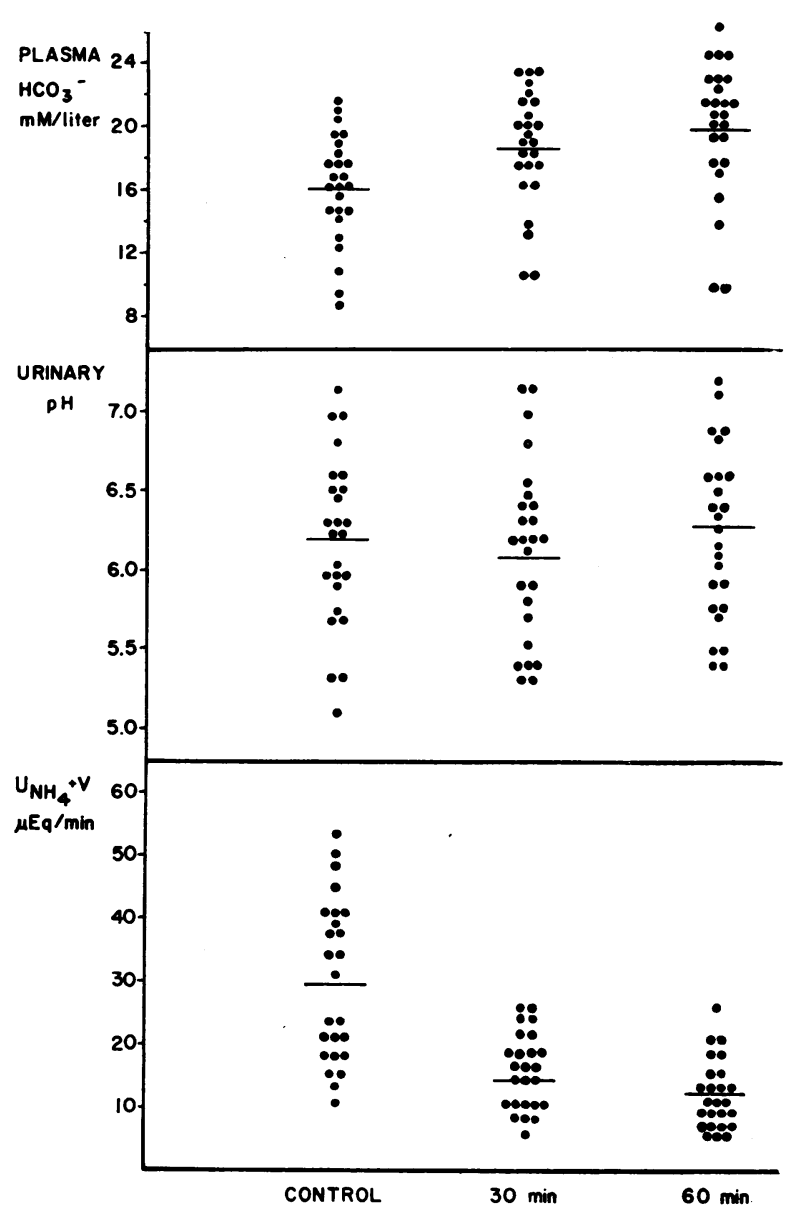

FIGURE 1 Effect of D,L- $\beta$-hydroxybutyrate ( $\mathrm{pH} 6.0$ ) on urinary excretion of ammonia (both kidneys) in acidotic dogs.
(Calbiochem, Los Angeles, Calif.) adjusted to $\mathrm{pH} 6.0$ was administered immediately after the three control periods. Simultaneously, a $5 \%$ mannitol solution containing $\mathrm{D}, \mathrm{L}-\boldsymbol{\beta}$ hydroxybutyrate also adjusted to $\mathrm{pH} 6.0$ and delivering 0.59 $\mathrm{mm}$ of ketone per min was started and maintained during the next $60-120 \mathrm{~min}$. At least six consecutive $10-\mathrm{min}$ urinary collections were taken either immediately after the beginning of ketone body infusion or after a $30-\mathrm{min}$ equilibrium interval. Urine was collected under mineral oil through inlying bladder catheter. Total production of ammonia by the left kidney was studied in 63 animals. The kidney was exposed through a midline abdominal incision and the renal vein catheterized through the inferior vena cava after ligation of the ovarian vein. The left ureter was catheterized and urine collected under mineral oil. Total ammonia production by the left kidney was taken as the sum of ammonia added to the renal vein plus that excreted in the urine per minute. In 20 animals $D, L-\beta$-hydroxybutyric acid as the sodium salt adjusted to $\mathrm{pH} 6.0$ was infused according to the protocol already outlined. In a second group of five animals, both the prime and the sustaining infusion of $\beta$ hydroxybutyrate were adjusted to $\mathrm{pH} 4.2$ by addition of an appropriate amount of hydrochloric acid. In a series of eight experiments, sodium acetoacetate prepared by hydrolyzing ethyl acetoacetate (4) was adjusted to $\mathrm{pH} 6.0$ and substituted to $\beta$-hydroxybutyrate in equimolar amounts. In order to simulate the rise in plasma bicarbonate concentration observed during the infusion of ketones adjusted to $\mathrm{pH}$ 6.0 , six animals were infused with $40 \mathrm{~mm}$ of sodium bicarbonate while six others received $80 \mathrm{~mm}$ of D,L-sodium lactate. In six animals, infusion of $5 \%$ mannitol alone was continued after the three control periods and maintained during the next $60-120 \mathrm{~min}$. Another group of seven animals received pure $\beta$-hydroxybutyric acid. The latter was prepared by processing sodium $\beta$-hydroxybutyrate through a strongly acidic cation exchange resin (Dowex $50 \mathrm{~W}-\mathrm{X} 8$, $20-50$ mesh). Sodium-free $\beta$-hydroxybutyric acid was infused in the same quantities as sodium $\beta$-hydroxybutyrate adjusted to either $\mathrm{pH} 6.0$ or 4.2. In these studies the $\mathrm{pH}$ of the sustaining solution was 3.6 while that of the prime was 2.2. In a final group of ten animals, $\beta$-hydroxybutyrate adjusted to $\mathrm{pH} 6.0$ was infused in the left renal artery at the rate of $0.1-1 \mathrm{~mm} / \mathrm{min}$. In these experiments, both ureters and renal veins were catheterized and ammonia production measured in each kidney.

The clearance of exogenous creatinine was used to estimate glomerular filtration rate and the corrected $\mathrm{PAH}$ (paraaminohippuric acid) clearance was taken as the measure of effective renal plasma flow. Total renal blood flow was calculated using the corresponding hematocrit value. Paraaminohippurate in arterial and venous plasma as well as urine was determined by the method of Bratton and Marshall modified by Smith, Finkelstein, Aliminosa, Crawford, and Graber (5). Total blood and urinary ketones were determined by the microdistillation technique of Lyon and Bloom (6). Whole blood ammonia was measured by the method of Humoller, Barak, and Holthaus (7). Arterial and venous blood samples for measurements of ammonia were drawn separately in cooled heparinized syringes containing ammonia-free mineral oil and $10 \mathrm{ml}$ of $100 \%$ carbon dioxide. These samples were kept in chopped ice and determination of ammonia was performed within $3 \mathrm{hr}$. Whole blood and urinary lactate was determined by the method of Horn and Bruns (8). Plasma and urinary glutamine was determined enzymatically with commercial Escherichia coli glutaminase (Worthington Biochemical Corp., Freehold, N. J.) (9). The renal extraction of glutamine 
TABLE I

Blood, Plasma, Urinary, and Renal Hemodynamic Values during $D, L-\beta$ Hydroxybutyrate Infusion ( $p H$ 6.0)

\begin{tabular}{|c|c|c|c|}
\hline & Control & $30 \mathrm{~min}$ & $60 \mathrm{~min}$ \\
\hline Blood pH & $7.29 \pm 0.02$ & $\begin{array}{l}7.34 \pm 0.02 \\
P<0.05\end{array}$ & $\begin{array}{l}7.37 \pm 0.02 \\
P<0.001\end{array}$ \\
\hline Plasma $\mathrm{P}_{\mathrm{CO}_{2}} \mathrm{~mm} \mathrm{Hg}$ & $37.6 \pm 1.07$ & $37.4 \pm 1.4$ & $37.4 \pm 1.4$ \\
\hline Plasma $\mathrm{HCO}_{3}, m M /$ liter & $16.2 \pm 0.6$ & $\begin{array}{c}18.7 \pm 0.7 \\
P<0.01\end{array}$ & $\begin{array}{c}19.9 \pm 0.8 \\
P<0.001\end{array}$ \\
\hline Plasma $\mathrm{Na}^{+}, m E q /$ liter & $146.0 \pm 1.3$ & $148.0 \pm 1.6$ & $148.0 \pm 1.0$ \\
\hline Plasma $\mathrm{K}^{+}, m E q /$ liter & $3.3 \pm 0.07$ & $3.0 \pm 0.04$ & $2.8 \pm 0.10$ \\
\hline Plasma $\mathrm{Cl}^{-}, m E q /$ liter & $114.0 \pm 3.4$ & $113.0 \pm 3.5$ & $110.0 \pm 3.2$ \\
\hline Blood ketones, $m M /$ liter & $P<0.1$ & $4.54 \pm 0.32$ & $3.9 \pm 0.31$ \\
\hline Urine flow, $\mathrm{ml} / \mathrm{min}$ & $3.9 \pm 0.2$ & $\begin{array}{l}5.4 \pm 0.4 \\
P<0.01\end{array}$ & $\begin{array}{l}5.1 \pm 0.4 \\
P<0.01\end{array}$ \\
\hline Urinary $\mathrm{pH}$ & $6.21 \pm 0.12$ & $6.00 \pm 0.13$ & $6.27 \pm 0.17$ \\
\hline $\mathrm{U}_{\mathrm{TA}} \mathrm{V}, \mu E q / \min$ & $19.0 \pm 2.0$ & $20.0 \pm 3.0$ & $16.0 \pm 3.0$ \\
\hline $\mathrm{U}_{\mathrm{NH}_{4}}+\mathrm{V}, \mu E q / \min$ & $30.0 \pm 3.0$ & $\begin{array}{c}15.0 \pm 1.0 \\
P<0.001\end{array}$ & $\begin{array}{c}12.0 \pm 1.0 \\
P<0.001\end{array}$ \\
\hline $\mathrm{U}_{\mathrm{HCO}_{3}}-\mathrm{V}, \mu E q / \min$ & $12.5 \pm 2.0$ & $13.9 \pm 4.9$ & $\begin{array}{l}22.1 \pm 5.4 \\
P<0.05\end{array}$ \\
\hline $\mathrm{U}_{\text {ketone }} \mathrm{V}, \mu M / \min$ & 0 & $34.0 \pm 3.7$ & $24.0 \pm 4.5$ \\
\hline $\mathrm{GFR}, \mathrm{ml} / \min$ & $57.0 \pm 3.0$ & $59.0 \pm 4.0$ & $61.0 \pm 4.0$ \\
\hline $\mathrm{RBF}, \operatorname{ml} / \min$ & $369.0 \pm 18.0$ & $339.0 \pm 24.0$ & $327.0 \pm 21.0$ \\
\hline
\end{tabular}

Values are means $\pm \mathrm{SE} ; n=25$.

was taken as the product of arteriovenous plasma concentration difference and corrected renal plasma flow. Blood and urine $\mathrm{pH}$, total carbon dioxide and creatinine in plasma and urine, urinary ammonia and titratable acid, as well as plasma and urinary sodium, potassium, chloride, and phosphorus, were determined by methods previously reported (10) with the exception of chloride which was measured electrometrically.

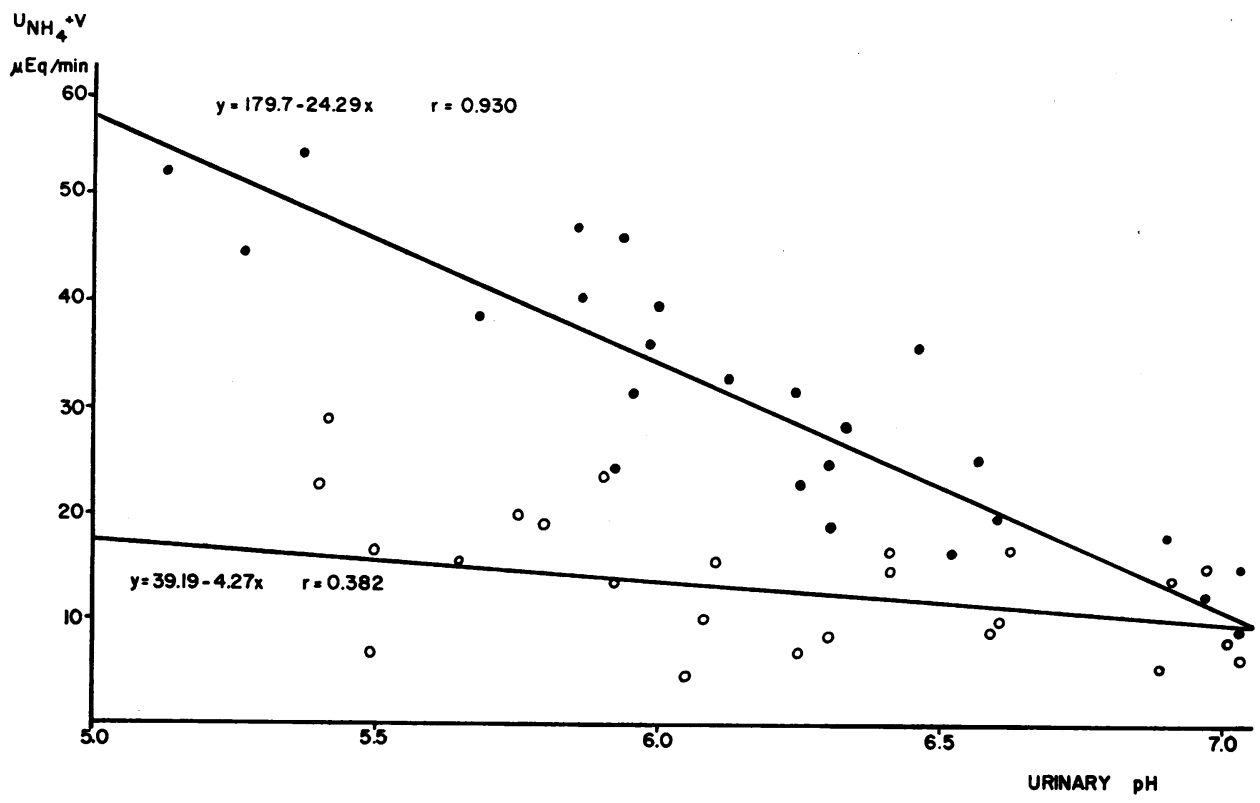

FIGURE 2 Relationship between urinary ammonia (both kidneys) and urinary $\mathrm{pH}$ during infusion of $D, L$ - $\beta$-hydroxybutyrate $(\mathrm{pH} 6.0)$ in acidotic dogs. The closed symbols represent control values and open symbols those obtained during infusion of ketones. 
TABLE II

Renal Extraction of Glutamine during $\beta$-Hydroxybutyrate Infusion ( $p H$ 6.0)

\begin{tabular}{lcccc}
\hline & Arterial plasma & Renal venous plasma & A-V difference & Renal extraction \\
\hline \multirow{3}{*}{ Control } & $\mu .553 \pm 0.021$ & $0.388 \pm 0.018$ & $+0.165 \pm 0.013$ & $+19.5 \pm 2.8$ \\
$30 \mathrm{~min}$ & $0.518 \pm 0.034$ & $0.548 \pm 0.034$ & $-0.030 \pm 0.046$ & $-3.5 \pm 5.3$ \\
& & $(P<0.05)$ & $(P<0.01)$ & $(P<0.05)$ \\
$60 \mathrm{~min}$ & $0.620 \pm 0.038$ & $0.610 \pm 0.037$ & $+0.010 \pm 0.019$ & $+1.0 \pm 2.6$ \\
& & $(P<0.05)$ & $(P<0.001)$ & $(P<0.001)$
\end{tabular}

Values are means $\pm \mathrm{SE} ; n=20$.

\section{RESULTS}

In the 25 experiments where $\beta$-hydroxybutyrate adjusted to $\mathrm{pH} 6.0$ was infused, a $50 \%$ decrement in urinary ammonia excretion was noted within $30 \mathrm{~min}$ and persisted throughout the duration of the infusion (Fig. 1 and Table I). As can be seen in Fig. 2, urinary ammonia values at any given $\mathrm{pH}$ were significantly lower than those observed during the control period. Furthermore, the usual relationship between urinary $\mathrm{pH}$ and ammonia excretion was completely abolished. Mean urinary $\mathrm{pH}$ did not differ significantly from control values while urine flow increased slightly (Fig. 1 and Table I). No important variation in either urinary titratable acid or bicarbonate excretion was noted during these experiments although bicarbonate excretion rose slightly after $60 \mathrm{~min}$ (Table I). The infusion of $\beta$-hydroxybutyrate resulted in partial or complete correction of metabolic acidosis. During the control period, blood $\mathrm{pH}$ averaged 7.29 and plasma bicarbonate $16.2 \mathrm{~mm} /$ liter. Blood $\mathrm{pH}$ rose to 7.34 after $30 \mathrm{~min}$ and 7.37 after $60 \mathrm{~min}$ while plasma bicarbonate rose simultaneously to 18.7 and $19.9 \mathrm{~mm} /$ liter (Table I). Mean plasma $\mathrm{Pco}_{2}$ averaged $37 \mathrm{~mm} \mathrm{Hg}$ throughout these experiments. All values for plasma bi- carbonate are shown in Fig. 1. During the control period, whole blood ketone concentration was less than 0.1 $\mathrm{mm} /$ liter and ketone bodies could not be detected in the urine. During ketone infusion, blood ketone concentration averaged $4.5 \mathrm{~mm} /$ liter and urinary excretion $34 \mu$ moles/ min after $30 \mathrm{~min}$ (Table I). No direct relationship between the rate of ketone excretion and urinary ammonia was noted. Glomerular filtration rate did not change during $\beta$-hydroxybutyrate infusion while renal blood flow showed a slight fall which did not exceed $11 \%$ of control values after $60 \mathrm{~min}$ (Table I).

Renal production of ammonia by the left kidney measured in the 20 other animals also infused with $\beta$-hydroxybutyrate at $\mathrm{pH} 6.0$ showed a marked and rapid decrease. During the control period, ammonia production averaged $26.5 \mu_{\mathrm{M}} / \mathrm{min} \pm 2.1 \mathrm{SE}$. This value decreased rapidly to $9.2 \mu \mathrm{M} / \mathrm{min} \pm 0.9 \mathrm{SE}(P<0.001)$ after $60 \mathrm{~min}$ of ketone infusion, a mean decrement of $65 \%$ (Fig. 3). In all experiments the ammonia content of both urine and renal venous blood fell markedly. When measured within $15 \mathrm{~min}$ after the onset of ketone infusion, ammonia production was found to be already strikingly depressed. No significant change in arterial plasma glutamine concentration could be detected during

TABLE III

The Effect of D,L- $\beta$-Hydroxybutyrate

\begin{tabular}{|c|c|c|c|c|c|c|c|c|c|}
\hline \multirow[b]{2}{*}{ Time } & \multirow[b]{2}{*}{$\begin{array}{c}\text { Blood } \\
\text { pH }\end{array}$} & \multirow[b]{2}{*}{ Htc } & \multirow[b]{2}{*}{$\begin{array}{l}\text { Plasma } \\
\mathrm{HCO}_{2}-\end{array}$} & \multicolumn{2}{|c|}{ Blood ketones } & \multicolumn{2}{|c|}{ Blood ammonia } & \multicolumn{2}{|c|}{ Plasma glutamine } \\
\hline & & & & Arterial & $\begin{array}{l}\text { Renal } \\
\text { venous }\end{array}$ & Arterial & $\begin{array}{c}\text { Renal } \\
\text { venous }\end{array}$ & Arterial & $\begin{array}{c}\text { Renal } \\
\text { venous }\end{array}$ \\
\hline $\min$ & & $\%$ & $m \mathrm{M} /$ liter & \multicolumn{2}{|c|}{$m \mathrm{M} /$ liter } & \multicolumn{2}{|c|}{$\boldsymbol{\mu} \mathbf{M} /$ liter } & \multicolumn{2}{|c|}{$\mu \mathrm{M} / m l$} \\
\hline $\begin{array}{r}0-10 \\
10-20\end{array}$ & 7.26 & 49 & 14.5 & $<0.1$ & $<0.1$ & 41 & 84 & 0.580 & 0.490 \\
\hline $\begin{array}{l}20-30 \\
30\end{array}$ & 7.26 & 48 & 15.0 & $<0.1$ & $<0.1$ & $\begin{array}{c}43 \\
\text { Infuse }\end{array}$ & $\begin{array}{c}87 \\
D, L-\beta\end{array}$ & $\begin{array}{r}0.565 \\
\text { roxybut }\end{array}$ & $\begin{array}{c}0.480 \\
(40 \mathrm{~mm})\end{array}$ \\
\hline $\begin{array}{l}60-70 \\
70-80 \\
80-90\end{array}$ & 7.31 & 48 & 16.8 & 5.2 & 4.8 & 36 & 57 & 0.550 & 0.520 \\
\hline $90-100$ & 7.39 & 46 & 19.5 & 5.0 & 4.5 & 30 & 49 & 0.600 & 0.585 \\
\hline
\end{tabular}


$\beta$-hydroxybutyrate infusion (Table II). However the renal venous concentration rose markedly so that arteriovenous difference was abolished (Table II). During the control period, renal extraction of glutamine averaged $19.5 \mu \mathrm{M} / \mathrm{min}( \pm 2.8 \mathrm{SE})$. Since renal plasma flow did not vary significantly while the plasma glutamine arteriovenous difference became negligible, the extraction value approached zero (Table II). Only trace amounts of glutamine could be detected in the urine. Renal utilization of ketones averaged $0.14 \mathrm{~mm} / \mathrm{min}$ per kidney $\pm 0.05 \mathrm{SE}$. A representative experiment is shown in Table III. Urinary cation-anion excretion balance measured in five animals is shown in Table IV. It can be seen that unmeasured anions after ketone infusion did not differ significantly from control values. This is entirely accounted for by the fact that appearance of ketone in the urine was balanced by a fall in chloride and a rise in sodium excretion.

In the five animals infused with $\beta$-hydroxybutyrate adjusted to $\mathrm{pH} 4.2$, the same decrement in renal ammoniogenesis was observed (Fig. 4) in spite of the fact that mean plasma bicarbonate fell from 16.6 to $13.4 \mathrm{~mm} /$ liter while urinary $\mathrm{pH}$ decreased from 6.00 to 5.50 . The eight animals infused with acetoacetate adjusted to $\mathrm{pH}$ 6.0 showed a $54 \%$ decrease in renal ammoniogenesis after 60 min (Fig. 4). In the latter experiments plasma bicarbonate rose from 15.2 to $18.0 \mathrm{~mm} /$ liter while whole blood ketone concentration averaged $5.5 \mathrm{~mm} /$ liter. In the 12 animals infused with either sodium bicarbonate or sodium lactate, plasma bicarbonate increased by a mean of $4.2 \mathrm{~mm} /$ liter while renal ammoniogenesis fell by only $15 \%$ (Fig. 4). In the animals infused with lactate, whole blood lactate rose from 1.6 to $6.6 . \mathrm{mm} /$ liter after $60 \mathrm{~min}$ while urinary excretion of lactate increased from 1.3 to $13 \mu_{\mathrm{M}} / \mathrm{min}$. In these experiments urinary $\mathrm{pH}$ increased only slightly by $0.25 \mathrm{pH}$ unit. The continuous infusion of $5 \%$ mannitol in six animals failed to influ-

\section{( $\mu$ M/KIDNEY per $\min$ )}

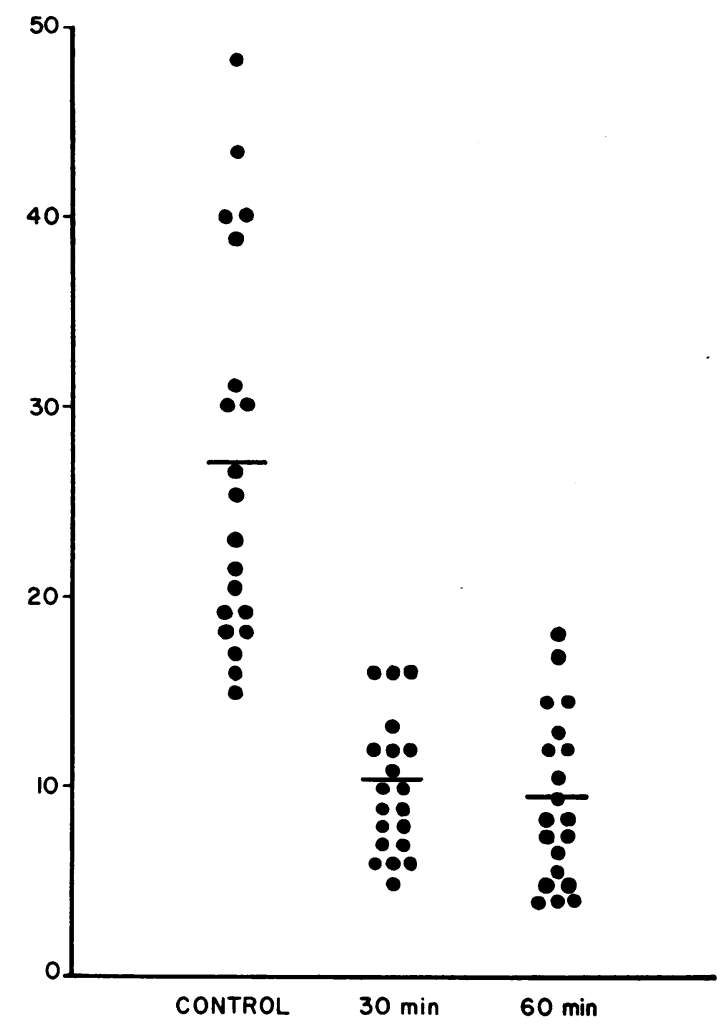

Figure 3 Ammonia production (left kidney) in acidotic animals during infusion of $\mathrm{D}, \mathrm{L}-\boldsymbol{\beta}$-hydroxybutyrate $(\mathrm{pH} 6.0)$.

ence renal ammoniogenesis (Fig. 4). In the seven animals infused with pure $\beta$-hydroxybutyric acid prepared by ion exchange, ammonia concentration fell in both urine and renal venous blood so that ammoniogenesis dropped by $50 \%$ in spite of the fact that urinary $\mathrm{pH}$ decreased from 6.35 to 5.63 while plasma bicarbonate fell

on Renal Ammoniogenesis in the Dog

\begin{tabular}{|c|c|c|c|c|c|c|c|c|c|c|c|}
\hline \multicolumn{6}{|c|}{ Urine (left kidney) } & \multicolumn{6}{|c|}{ Left kidney } \\
\hline Volume & $\mathrm{pH}$ & $\begin{array}{l}\text { Titratable } \\
\text { acid }\end{array}$ & $\mathrm{UNH}_{4}+\mathrm{V}$ & $\mathrm{UHCO}_{3}{ }^{-} \mathrm{V}$ & Ketones & GFR & СРАН & $\begin{array}{l}\text { Renal } \\
\text { blood } \\
\text { flow }\end{array}$ & $\begin{array}{c}\text { Total } \\
\text { ammonia } \\
\text { production }\end{array}$ & $\begin{array}{l}\text { Glutamine } \\
\text { extraction }\end{array}$ & $\begin{array}{c}\text { Ketone } \\
\text { utilization }\end{array}$ \\
\hline$m l / m i n$ & & $\mu E q / \min$ & $\mu E q / \min$ & $\mu E q / \min$ & $\mu \mathrm{M} / \min$ & $m l / m i n$ & $m l / m i n$ & $m l / m i n$ & $\mu E q / \min$ & $\mu \mathrm{M} / \min$ & $m \mathrm{M} / \min$ \\
\hline 2.1 & 6.35 & 4.62 & 13.04 & 6.51 & 0 & 28 & 162 & 317 & 26.67 & 14.58 & - \\
\hline 2.1 & 6.22 & 4.62 & 15.46 & 5.25 & 0 & 30 & 157 & 305 & & & \\
\hline 1.7 & 6.08 & 3.40 & 12.63 & 2.72 & 0 & 30 & 154 & 296 & 25.65 & 13.09 & - \\
\hline \multicolumn{12}{|c|}{ and sustaining solution $(0.59 \mathrm{~mm} / \mathrm{min}$ at $\mathrm{pH} 6.0)$} \\
\hline 2.1 & 5.78 & 1.99 & 7.96 & 1.68 & 24.2 & 29 & 146 & 281 & 13.86 & 4.38 & 0.88 \\
\hline 2.3 & 5.85 & 8.74 & 8.05 & 2.07 & 21.2 & 31 & 152 & 290 & & & \\
\hline 2.2 & 5.92 & 4.62 & 5.96 & 1.76 & 18.3 & 30 & 139 & 262 & & & \\
\hline 2.3 & 6.15 & 4.60 & 6.58 & 3.68 & 18.0 & 28 & 144 & 267 & 11.65 & 2.16 & 1.16 \\
\hline
\end{tabular}




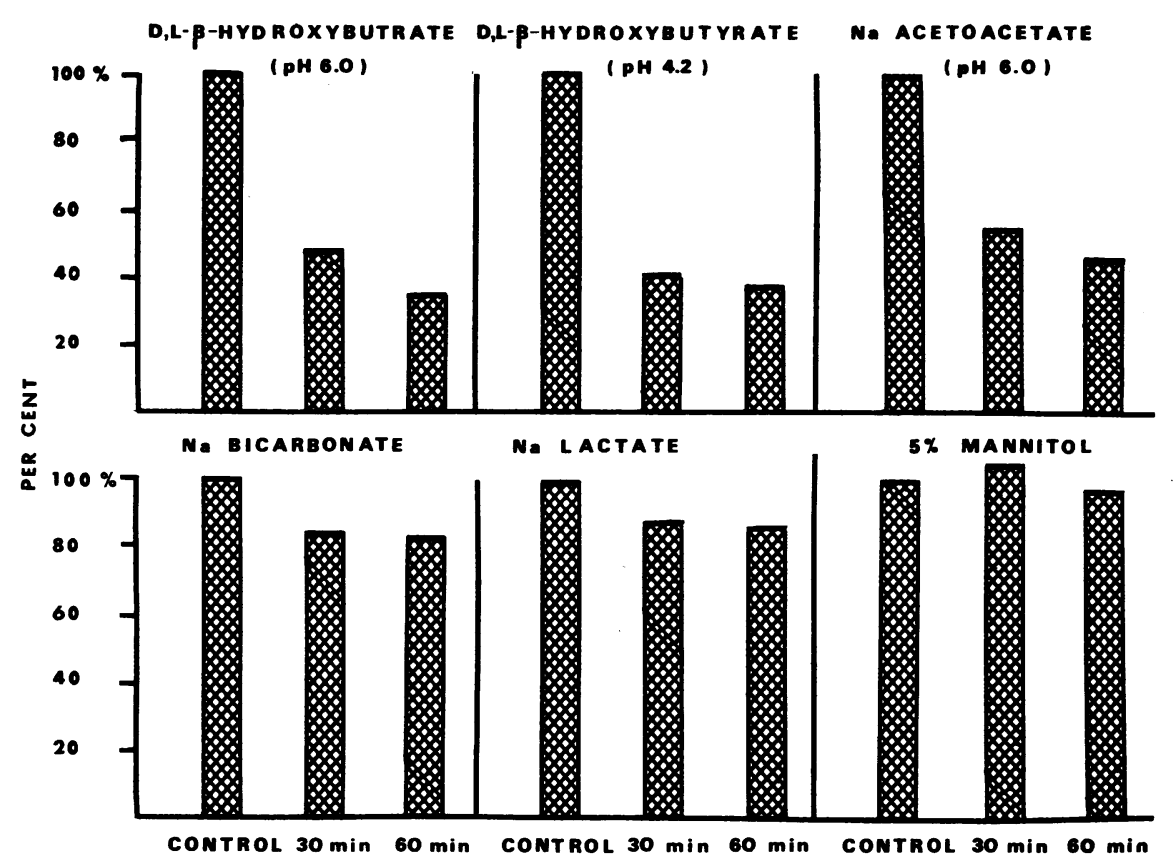

FIGURE 4 Ammonia production (left kidney) as per cent of control during infusion of $\mathrm{D}, \mathrm{L}-\boldsymbol{\beta}$-hydroxybutyrate $(\mathrm{pH} 6.0$ or 4.2 ), acetoacetate ( $\mathrm{pH} 6.0$ ), sodium bicarbonate, sodium lactate, and $5 \%$ mannitol.

from 17.6 to $14.5 \mathrm{~mm} /$ liter (Fig. 5). In contrast to previous experiments with ketones as their sodium salts, titratable acid excretion almost doubled the mean value rising from 9.0 to $16.6 \mu \mathrm{Eq} / \mathrm{min}$.

The infusion of $\beta$-hydroxybutyrate in the left renal artery resulted in a rapid decrease in ammonia production by the perfused kidney within the first $10 \mathrm{~min}$ of infusion. With time the control kidney also showed a depression in ammoniogenesis which always remained inferior to that observed in the experimental kidney when the rate of infusion of $\beta$-hydroxybutyrate was less than $0.6 \mathrm{~mm} / \mathrm{min}$. In the experiment shown in Table $\mathrm{V}$ infusion of $\beta$-hydroxybutyrate in the left renal artery at the rate of $0.3 \mathrm{~mm} / \mathrm{min}$ resulted in a 33 and $45 \%$ depression in ammonia production by the perfused kidney after 10 and 40 min while the control kidney showed a 6 and $31 \%$ drop during the same periods.

\section{DISCUSSION}

The present study clearly demonstrates that ketone body infusion induces a marked decrease in renal ammoniogenesis in the acidotic dog. This effect appears to be independent of urinary $\mathrm{pH}$ changes or variations in systemic acid-base status. In the 25 initial experiments where the animals were infused with $\beta$-hydroxybutyrate, the observed reduction in urinary ammonia excretion could not be related to diminished $\mathrm{pH}$ dependent diff $\mathrm{u}$ sion of ammonia in the tubular lumen since urinary $\mathrm{pH}$ remained constant while both titratable acid and bicarbonate excretion did not vary significantly. It is of interest that in all animals infused with either $\beta$-hydroxybutyrate or acetoacetate adjusted to $\mathrm{pH} 6.0$ plasma bicarbonate concentration rose by 3-4 $\mathrm{mm}$ /liter. This modest rise in extracellular bicarbonate can readily be explained by the metabolic fate of salts of organic acids $(11,12)$. It is unlikely that such a small increase in extracellular bicarbonate concentration played a significant role in depressing ammoniogenesis since a similar rise in plasma bicarbonate induced by the administration of either sodium bicarbonate or sodium lactate had little influence on ammonia production. Furthermore, the fact that $\beta$-hydroxybutyrate adjusted to $\mathrm{pH} 4.2$ or sodium-free $\beta$-hydroxybutyric acid had the same inhibitory effect on renal ammoniogenesis in spite of a fall in plasma bicarbonate concentration and urinary $\mathrm{pH}$ indicates that the effect of ketones on ammoniogenesis in the previous experiments was not related to partial correction of extracellular acidosis. The significant rise in titratable acid observed during the infusion of pure $\beta$-hydroxybutyric acid cannot explain the concomitant fall in urinary ammonia excretion since it has been shown in this laboratory (unpublished experiments) that the infusion of acid monosodium phosphate $\left(\mathrm{NaH}_{2} \mathrm{PO}_{4}\right)$ to acidotic dogs is never accompanied by a reduction in urinary ammonia excretion notwithstanding considerable increase in titratable acid excretion. 
Since renal blood flow and glomerular filtration rate did not vary significantly during ketone body infusion, there is no reason to believe that ammonia precursors such as glutamine and $\alpha$-amino acids like glycine failed to reach the renal tubular cell in appropriate amounts because of disturbed hemodynamics. We are aware of no evidence suggesting that ketone bodies acutely inhibit the synthesis of ammonia precursors in the liver. The fact that arterial plasma concentration of glutamine did not vary during ketone infusion constitutes evidence against an inhibitory effect on the synthesis of ammonia precursors. In addition, the rapid and unilateral depression of ammoniogenesis during infusion of $\beta$-hydroxybutyrate in the renal artery indicates that ketone bodies do not affect ammonia production through an extrarenal mechanism. It thus appears that ketone bodies exert their inhibitory influence within the renal tubular cell. The precise nature of this inhibition cannot be established by the present study. Although there is no available evidence suggesting that ketone bodies inhibit glutaminase I or II activity in the mammalian kidney it is clear that the observed depression in ammoniogenesis is associated with a marked decrease in the renal extraction of glutamine.

In view of the well-established and striking increase in urinary ammonia excretion observed during starvation (3) and diabetic ketosis (1) in man, the present findings are somewhat surprising. It is recognized that the present experimental situation is acute and distinct from the complex metabolic states of starvation and diabetic ketosis. It is usually considered that in the latter clinical circumstances, metabolic acidosis is the prime factor responsible for accelerated renal ammoniogenesis (13). At first, we entertained the possibility that infusion of sodium salts of ketones could induce alkalinization of the renal tubular cell $(11,12)$. As proposed by Pitts such an effect would result in a decreased NAD/NADH ratio, increased conversion of $\alpha$-ketoglutarate to glutamate and a fall in ammonia production (14). It has been shown that glutamate (15) and $\alpha$-ketoglutarate (16) accumulate in the rat kidney during metabolic alkalosis while glutaminase I activity is depressed $(15,17,18)$. It is unlikely however that ketone bodies exert their in-

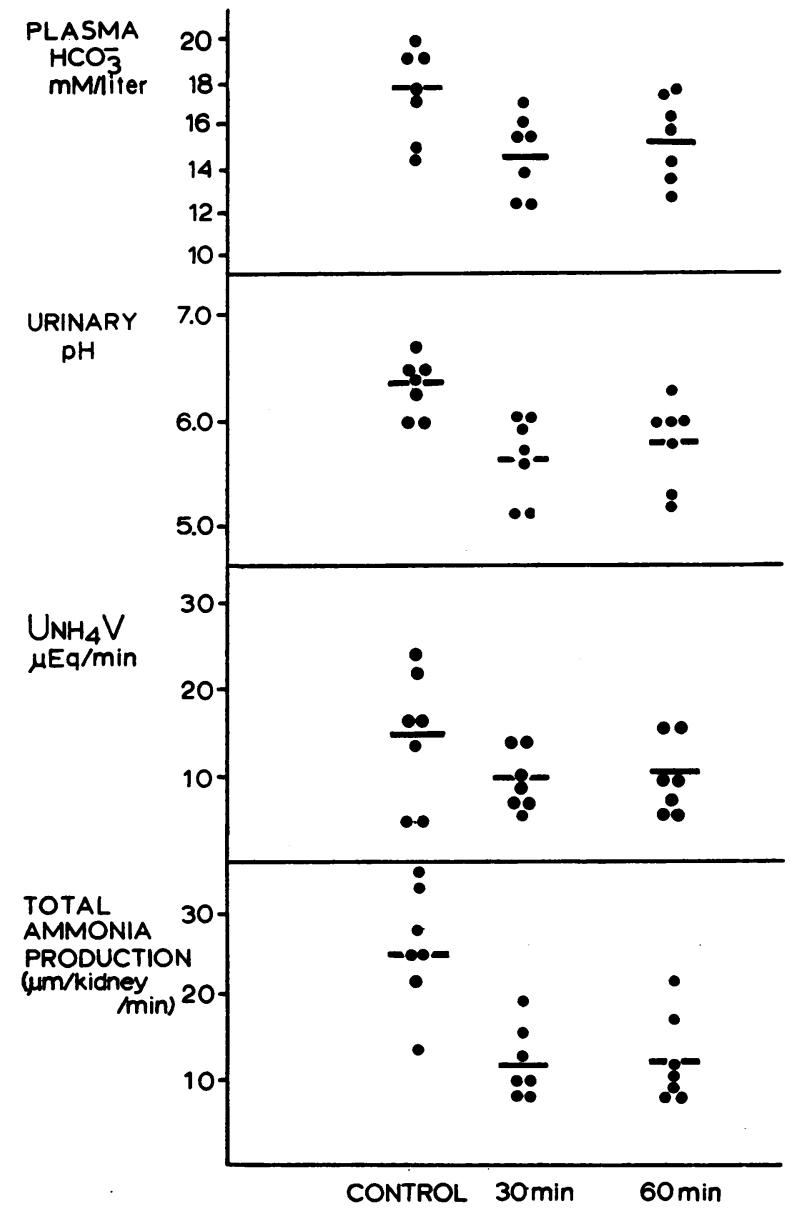

FIgURE 5 Effect of sodium-free $D, L-\beta$-hydroxybutyric acid $(\mathrm{pH} 2.2)$ on urinary excretion and ammonia production (left kidney) in acidotic dogs.

hibitory effect on renal ammonia production through such a mechanism since the infusion of pure $\beta$-hydroxybutyric acid had the same depressing effect in spite of the fact that metabolic acidosis was accentuated. It is difficult to conceive that a readily permeant organic acid such as $\beta$-hydroxybutyric acid could have produced intracellular alkalosis under such circumstances. In addition, it should be recalled that infusion of D,L-sodium

TABLE IV

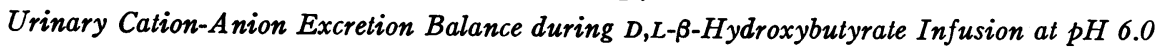

\begin{tabular}{|c|c|c|c|c|c|c|c|c|c|c|}
\hline & $\mathrm{Na}^{+}$ & $\mathrm{K}^{+}$ & $\mathrm{TA}$ & $\mathrm{NH}_{4}^{+}$ & $\begin{array}{c}\text { Total } \\
\text { measured } \\
\text { cations }\end{array}$ & $\begin{array}{c}\text { Total } \\
\text { measured } \\
\text { anions }\end{array}$ & $\mathrm{C1}^{-}$ & $\mathrm{HCO}_{3}^{-}$ & Ketone & $\begin{array}{l}\text { Unmea- } \\
\text { sured } \\
\text { anions }\end{array}$ \\
\hline & \multicolumn{8}{|c|}{$\mu E q / \min$} & $\mu \mathrm{M} / \min$ & $\mu E_{Q} / \min$ \\
\hline Control & $75 \pm 6$ & $14 \pm 3$ & $11 \pm 2$ & $12.3 \pm 0.6$ & 112 & 103 & $92 \pm 7$ & $11 \pm 2$ & 0 & 9 \\
\hline Ketone infusion & $113 \pm 7$ & $17 \pm 3$ & $11 \pm 2$ & $6.5 \pm 0.4$ & 147 & 134 & $76 \pm 7$ & $9 \pm 2$ & $49 \pm 4$ & 13 \\
\hline
\end{tabular}

Values are means $\pm \mathrm{SE} ; n=5$. 
TABLE $\mathrm{V}$

Ammonia Production by each Kidney during $D, L$

\begin{tabular}{|c|c|c|c|c|c|c|c|c|c|c|}
\hline \multirow[b]{3}{*}{ Time } & \multirow{3}{*}{$\begin{array}{l}\text { Blood } \\
\text { pH }\end{array}$} & \multirow{3}{*}{$\begin{array}{l}\text { Plasma } \\
\mathrm{HCO}_{3}^{-}\end{array}$} & \multirow{3}{*}{$\begin{array}{l}\text { Arterial } \\
\text { blood } \\
\text { ketones }\end{array}$} & \multicolumn{3}{|c|}{ Blood Ammonia } & \multicolumn{4}{|c|}{ Urine } \\
\hline & & & & \multirow[t]{2}{*}{ Arterial } & \multicolumn{2}{|c|}{ Renal venous } & \multicolumn{2}{|c|}{ Volume } & \multicolumn{2}{|c|}{$\mathrm{pH}$} \\
\hline & & & & & $\mathbf{R}$ & $\mathbf{L}$ & $\mathbf{R}$ & $\mathbf{L}$ & $\mathbf{R}$ & $\mathbf{L}$ \\
\hline $\min$ & & $m \mathrm{M} /$ liter & $m \mathrm{M} /$ liter & $\mu \mathrm{M} /$ liter & \multicolumn{2}{|c|}{$\mu \mathrm{M} /$ liter } & \multicolumn{2}{|c|}{$m l / \min$} & & \\
\hline $0-10$ & 7.30 & 16.9 & $<0.1$ & 26 & 97 & 84 & 1.2 & 1.5 & 5.60 & 5.53 \\
\hline 10-20 & & & & & & & 1.3 & 1.8 & 5.61 & 5.50 \\
\hline $20-30$ & 7.30 & 16.2 & $<0.1$ & 27 & 104 & 98 & 1.2 & 1.8 & 5.50 & 5.42 \\
\hline 30 & & & & & \multicolumn{6}{|c|}{ Infuse $D, L-\beta$-hydroxybutyrate $0.3 \mathrm{~mm} / \mathrm{ml}$ per $\min$} \\
\hline $30-40$ & & & & & & & 1.2 & 2.5 & 5.45 & 5.38 \\
\hline $40-50$ & 7.30 & 17.2 & 0.40 & 26 & 85 & 51 & 1.4 & 2.6 & 5.40 & 5.33 \\
\hline $50-60$ & & & & & & & 1.4 & 2.3 & 5.40 & 5.29 \\
\hline $60-70$ & 7.31 & 17.8 & 1.14 & 26 & 69 & 48 & 1.4 & 2.4 & 5.39 & 5.25 \\
\hline $70-80$ & & & & & & & 1.5 & 2.4 & 5.53 & 5.25 \\
\hline 80-90 & & & & & & & 1.6 & 2.5 & 5.50 & 5.18 \\
\hline 90-100 & 7.30 & 21.0 & 1.50 & 23 & 64 & 39 & 1.7 & 2.5 & 5.40 & 5.20 \\
\hline
\end{tabular}

R, Right kidney; L, Left kidney.

lactate sufficient to elevate extracellular plasma bicarbonate by $4 \mathrm{~mm} /$ liter failed to influence renal ammoniogenesis.

The redox state of nicotinamide adenine dinucleotide in the mitochondria of the renal tubular cell is now viewed as an important factor in renal ammoniogenesis.

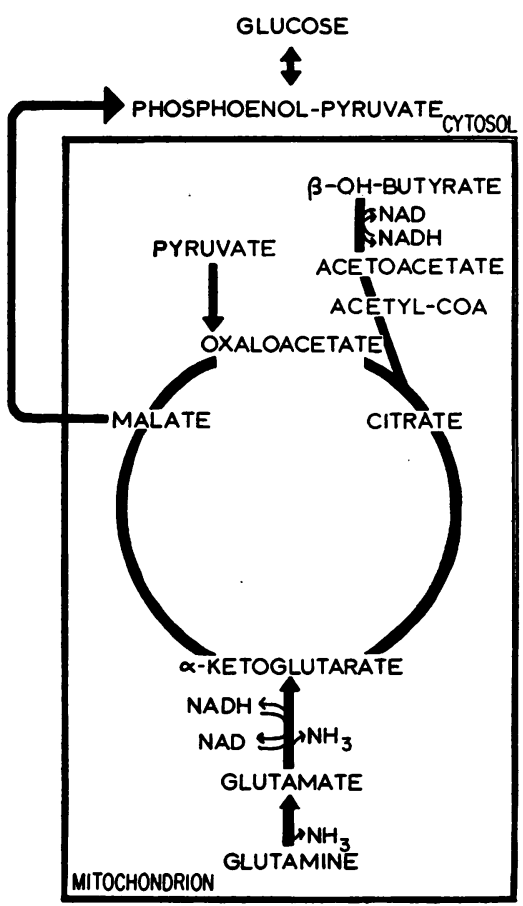

FIgURe 6 Metabolic pathways of ketone bodies and glutamine in the mitochondria of the renal tubular cell. See text for discussion.
This was first suggested by Pitts (14) and later demonstrated by Preuss $(19,20)$. It has been shown that the accelerated renal ammoniogenesis observed in metabolic acidosis is associated with an increased NAD/NADH ratio in the rat kidney $(19,20)$. Williamson, Lund, and Krebs have demonstrataed that the glutamate and $\beta$-hydroxybutyrate dehydrogenase systems in the mitochondria of the rat liver are in equilibrium with a common NAD/NADH pool (21). On the other hand the oxidation of $\beta$-hydroxybutyrate to acetoacetate within liver and kidney mitochondria is accompanied by a reduction of NAD/NADH ratio (22-25). One is tempted to postulate that during the infusion of ketone bodies, transformation of $\beta$-hydroxybutyrate in the mitochondria of the dog renal tubular cell results in a significant decrease in the NAD/NADH ratio. This would favor diminished production of ammonia through accelerated conversion of $\alpha$-ketoglutarate to glutamate. The fact that acetoacetate had grossly the same effect as $\beta$-hydroxybutyrate does not necessarily exclude such a mechanism since acetoacetate is rapidly converted to $\beta$-hydroxybutyrate in vivo (2628).

It is well-known that ketone bodies can be used as preferential respiratory fuel in the renal cortex where they are oxidized to acetyl Co-A $(24,25,29-33)$. The latter is coupled with oxaloacetate to form citrate under the catalytic activity of citrate synthetase and is thus incorporated in the tricarboxylic acid cycle (Fig. 6). It is quite possible that accelerated formation of citrate through increased condensation of acetyl-CoA and oxaloacetate $(24,34,35)$ induces increased production of $\alpha$-ketoglutarate which will prevent deamination of glutamate $(36,37)$ (Fig. 6). Such a sequence of events 


\begin{tabular}{|c|c|c|c|c|c|c|c|c|c|}
\hline \multicolumn{4}{|c|}{ Urine } & \multirow{2}{*}{\multicolumn{2}{|c|}{ GFR }} & \multirow{2}{*}{\multicolumn{2}{|c|}{ Renal blood flow }} & \multirow{2}{*}{\multicolumn{2}{|c|}{$\begin{array}{l}\text { Total ammonia } \\
\text { production }\end{array}$}} \\
\hline \multicolumn{2}{|c|}{$\mathrm{UNH}_{4}+\mathrm{V}$} & \multicolumn{2}{|c|}{ U ketones $\mathrm{V}$} & & & & & & \\
\hline $\mathbf{R}$ & L & $\mathbf{R}$ & L & $\mathbf{R}$ & L & $\mathbf{R}$ & $\mathbf{L}$ & $\mathbf{R}$ & $\mathbf{L}$ \\
\hline \multicolumn{2}{|c|}{$\mu E q / \min$} & \multicolumn{2}{|c|}{$\mu \mathrm{M} / \min$} & \multicolumn{2}{|c|}{$m l / m i n$} & \multicolumn{2}{|c|}{$m l / \min$} & \multicolumn{2}{|c|}{$\mu E q / \min$} \\
\hline 15.4 & 22.1 & 0 & 0 & 27 & 27 & 126 & 149 & 24.35 & 30.74 \\
\hline 17.0 & 24.8 & 0 & 0 & 26 & 30 & 124 & 156 & & \\
\hline 15.8 & 20.9 & 0 & $\mathbf{0}$ & 22 & 28 & 111 & 140 & 24.35 & 30.84 \\
\hline \multicolumn{10}{|c|}{$(\mathrm{pH} \mathrm{6.0)}$ in the left renal artery } \\
\hline 15.1 & 20.5 & 1.4 & 12.3 & 23 & 30 & 118 & 170 & & \\
\hline 15.5 & 16.4 & 2.0 & 16.1 & 26 & 28 & 125 & 172 & 22.88 & 20.70 \\
\hline 13.9 & 14.5 & 2.0 & 20.3 & 23 & 26 & 122 & 157 & & \\
\hline 11.3 & 11.8 & 2.8 & 20.0 & 23 & 27 & 123 & 165 & 16.60 & 15.43 \\
\hline 12.6 & 12.4 & 6.6 & 18.0 & 24 & 27 & 125 & 151 & & \\
\hline 13.9 & 15.0 & 6.2 & 20.5 & 22 & 25 & 122 & 156 & & \\
\hline 13.3 & 14.0 & 4.9 & 16.5 & 22 & 25 & 125 & 156 & 18.43 & 16.50 \\
\hline
\end{tabular}

would lead to marked depression of glutamine deamination and ammoniogenesis (38-40).

The respective effect of the $\mathrm{D}(-)$ or $\mathrm{L}(+)$ isomer of $\beta$-hydroxybutyrate cannot be established by the present observations since $\beta$-hydroxybutyrate was infused as the racemic mixture. It has been demonstrated however that both isomers are oxidized by the mitochondria of the rat kidney $(24,25)$. Available evidence indicates that $D$ $(-) \beta$-hydroxybutyrate is converted to free acetoacetate via the diphosphopyridine nucleotide-specific $D(-)$ $\beta$-hydroxybutyrate dehydrogenase system while the $\mathrm{L}$ $(+)$ isomer is first activated to its coenzyme A ester before being oxidized to acetoacetyl-coenzyme A (24, 25 . On this basis either isomer could inhibit renal ammoniogenesis through already discussed mechanisms. Since acetoacetate is readily reduced in vivo to $\mathbf{D}(-)$ $\beta$-hydroxybutyrate $(23,26,28)$ the observed inhibition of ammoniogenesis during acetoacetate infusion could be explained by alterations in the renal mitochondrial redox potential. A specific influence of $\mathrm{L}(+) \beta$-hydroxybutyrate and acetoacetate on ammoniogenesis remains to be determined. This might be complicated by the fact that reversible interconversion of the two stereoisomers of $\beta$-hydroxybutyrate coenzyme $\mathrm{A}$ ester has been demonstrated in extracts of mitochondria from rat kidney (41).

Whatever the mechanism whereby infused ketone bodies inhibit renal ammoniogenesis in the dog, one is faced with the difficult task of conciliating the present observations with the well-known and significant increase in renal ammoniogenesis observed in man during starvation and uncontrolled diabetes where ketone bodies are endogenously produced $(1,3)$. A marked elevation in plasma free fatty acids is a primary event in these pathological states $(42,43)$. This situation is quite different from our experimental conditions. Fatty acids have been shown to inhibit citrate synthetase $(44,45)$ and glycolysis at various stages in the liver (46-48). Such an effect, if it also occurs in the kidney, would facilitate gluconeogenesis from glutamate intermediates and at the same time stimulate ammoniogenesis. This situation would be similar to that observed in any form of metabolic acidosis (49-51). It is recognized that species differences may occur between man and dog since this animal fails to develop significant ketosis during prolonged starvation (52). Nevertheless, it is of interest that the fasting dog shows only a slight increment in plasma free fatty acids during prolonged starvation while urinary excretion of ammonia acutally decreases (52).

\section{ACKNOWLEDGMENTS}

The skilled technical assistance of Misses Rita Deschênes, Andrée Quenneville, Laurence Lavoie, Grace ThornleyBrown, Muriel Green, Gisèle Gaudreau, and Lys-Aurore Lapierre, as well as that of MMr. François Pellerin and Léon Normandeau is gratefully acknowledged.

This work was supported by Grants from the Medical Research Council of Canada and the Canadian Arthritis and Rheumatism Society.

\section{REFERENCES}

1. Peters, J. P., and D. D. Van Slyke. 1946. In Quantitative Clinical Chemistry. Interpretation. The Williams $\&$ Wilkins Co., Baltimore. 2nd edition. 885 .

2. Pitts, R. F. 1945. The renal regulation of acid base balance with special reference to the mechanism for acidifying the urine. Science (Washington). 102: 49. 
3. Rapoport, A., G. L. A. From, and H. Husdan. 1965. Metabolic studies in prolonged fasting. I. Inorganic metabolism and kidney function. Metab. Clin. Exp. 14: 31.

4. Golfinger, S., J. R. Klinenberg, and J. E. Seegmiller. 1965. Renal retention of uric acid induced by infusion of beta-hydroxybutyrate and acetoacetate. N. Engl. J. Med. 272: 351.

5. Smith, H. W., N. Finkelstein, L. Aliminosa, B. Crawford, and M. Graber. 1945. The renal clearances of substituted hippuric acid derivatives and other aromatic acids in dog and man. J. Clin. Invest. 24: 388.

6. Lyon, J. B. Jr., and W. L. Bloom. 1958. The use of furfural for the determination of acetone bodies in biological fluids. Can. J. Biochem. Physiol. 36: 1047.

7. Humoller, F. L., A. J. Barak, and J. M. Holthaus. 1964. Distribution of ammonia in cells and plasma. Clin. Chem. 10: 589 .

8. Horn, H. D., and F. H. Bruns. 1956. Quantitative bestimmung von $\mathrm{L}(+)$-Milchsäure mit Milchsäuredehydrogenase. Biochim. Biophys. Acta. 21: 378.

9. Sherrard, D. J., and D. P. Simpson. 1969. An improved method for the microdetermination of glutamine in plasma and urine. J. Lab. Clin. Med. 73: 877.

10. Lemieux, G., and M. Gervais. 1964. Acute chloride depletion alkalosis : effect of anions on its maintenance and correction. Amer. J. Physiol. 207: 1279.

11. Lipsky, S. R., B. J. Alper, M. E. Rubini, W. F. Van Eck, and M. E. Gordon. 1954. The effects of alkalosis upon ketone body production and carbohydrate metabolism in man. J. Clin. Invest. 33: 1269.

12. Winters, R. W., K. Engel, and R. B. Dell. 1967. Metabolic alkalosis. In Acid Base Physiology in Medicine. The London Company of Cleveland and Radiometer A/S of Copenhagen. Sec. 8. 192.

13. Kamm, D. E., and G. F. Cahill, Jr. 1969. Effect of acidbase status on renal and hepatic gluconeogenesis in diabetes and fasting. Amer. J. Physiol. 216: 1207.

14. Pitts, R. F. 1966. The renal metabolism of ammonia. Physiologist. 9: 97.

15. Goldstein, L. 1966. Relation of glutamate to ammonia production in the rat kidney. Amer. J. Physiol. 210: 661.

16. Narins, R. G., and A. S. Relman. 1970. Metabolic changes in renal cortex and medulla in chronic acidosis and alkalosis. Clin. Res. 18: 511 .

17. Goldstein, L., and J. H. Copenhaver, Jr. 1960. Relation of glutaminase I activity to glutamic acid concentration in the rat kidney. Amer. J. Physiol. 198: 227.

18. Goldstein, L., and J. M. Shooler. 1966. Regulation of ammonia production in the rat kidney. Advan. Enzyme Regul. 5: 71.

19. Preuss, H. G. 1968. Pyridine nucleotides in renal ammonia metabolism. J. Lab. Clin. Med. 72: 370.

20. Preuss, H. G. 1969. Renal glutamate metabolism in acute metabolic acidosis. Nephron. 6: 235.

21. Williamson, D. H., P. Lund, and H. A. Krebs. 1967. The redox state of free nicotinamide-adenine dinucleotide in the cytoplasm and mitochondria of rat liver. Biochem. J. 103 : 514.

22. Devlin, T. M., and B. H. Bedell. 1960. Effect of acetoacetate on the oxidation of reduced diphosphopyridine nucleotide by intact rat liver mitochondria. J. Biol. Chem. 235: 2134.

23. Krebs, H. A. 1961. The physiological role of the ketone bodies. Biochem. J. 80: 225 .

24. Lehninger, A. L., and G. D. Greville. 1953. The enzy- mic oxidation of $\mathrm{d}$ - and $1-\beta$-hydroxybutyrate. Biochim. Biophys. Acta. 12: 188.

25. McCann, W. P. 1957. The oxidation of ketone bodies by mitochondria from liver and peripheral tissues. J. Biol. Chem. 226: 15.

26. Marriott, W. McK. 1914. The metabolic relationships of the acetone substances. J. Biol. Chem. 18: 241.

27. Schwab, L., and W. D. Lotspeich. 1954. Renal tubular reabsorption of acetoacetate in the dog. Amer. J. Physiol. 176: 195.

28. McGarry, J. D., M. J. Guest, and D. W. Foster. 1970. Ketone body metabolism in the ketosis of starvation and alloxan diabetes. J. Biol. Chem. 245: 4382.

29. Krebs, H. A., R. N. Speake, and R. Hems. 1965. Acceleration of renal gluconeogenesis by ketone bodies and fatty acids. Biochem. J. 94: 712.

30. Underwood, A. H., and E. A. Newsholme. 1967. Control of glycolysis and gluconeogenesis in rat kidney cortex slices. Biochem. J. 104: 300.

31. Nishiitsutsuji-Uwo, J. M., B. D. Ross, and H. A. Krebs. 1967. Metabolic activities of the isolated perfused rat kidney. Biochem. J. 103: 852.

32. Krebs, H. A., R. Hems, M. J. Weidemann, and R. N. Speake. 1966. The fate of isotopic carbon in kidney cortex synthesizing glucose from lactate. Biochem. J. 101 242.

33. Newsholme, E. A., and A. H. Underwood. 1966. The control of glycolysis and gluconeogenesis in kidney cortex. Biochem. J. 99: 24c.

34. Srere, P. A. 1965. The molecular physiology of citrate. Nature (London). 205: 766.

35. Parmeggiani, A., and R. H. Bowman. 1963. Regulation of phosphofructokinase activity by citrate in normal and diabetic muscle. Biochem. Biophys. Res. Commun. 12: 268.

36. Hird, F. J. R., and M. A. Marginson. 1968. The formation of ammonia from glutamine and glutamate by mitochondria from rat liver and kidney. Arch. Biochem. Biophys. 127: 718 .

37. Balagura-Baruch, S., L. M. Shurland, and T. C. Welbourne. 1970. Effects of $\alpha$-ketoglutarate on renal ammonia release in the intact dog. Amer. J. Physiol. 218: 1070.

38. Klingman, J. D., and P. Handler. 1958. Partial purification and properties of renal glutaminase. J. Biol. Chem. 232: 369 .

39. Sayre, F. W., and E. Roberts. 1958. Preparation and some properties of a phosphate-activated glutaminase from kidneys. J. Biol. Chem. 233: 1128.

40. Goldstein, L. 1967. Pathways of glutamine deamination and their control in the rat kidney. Amer. J. Physiol. 213: 983.

41. Stern, J. R., A. Del Campillo, and A. L. Lehninger. 1955. Enzymatic racemization of $\beta$-hydroxybutyryl-S-CoA and the stereospecificity of enzymes of the fatty acid cycle. J. Amer. Chem. Soc. 77: 1073.

42. Krebs, H. A. 1966. The regulation of the release of ketone bodies by the liver. Advan. Enzyme Regul. 4: 339.

43. Wieland, O., and L. Weiss. 1963. Increase in liver acetyl-coenzyme A during ketosis. Biochem. Biophys. Res. Commun. 10: 333.

44. Wieland, O., and L. Weiss. 1963. Inhibition of citrate synthase by palmityl coenzyme A. Biochem. Biophys. Res. Commun. 13: 26.

45. Tubbs, P. K. 1963. Inhibition of citrate formation by long-chain acyl thioesters of Coenzyme $A$ as a possible 
control mechanism in fatty acid biosynthesis. Biochim. Biophys. Acta. 70: 608.

46. Weber, G., M. A. Lea, and N. B. Stamm. 1968. Sequential feedback inhibition and regulation of liver carbohydrate metabolism through control of enzyme activity. Advan. Enzyme Regul. 6: 101.

47. Weber, G., M. A. Lea, H. J. H. Convery, and N. B. Stamm. 1967. Regulation of gluconeogenesis and glucolysis: studies of mechanisms controlling enzyme activity. Advan. Enzyme Regul. 5: 257.

48. Lea, M. A., and G. Weber. 1968. Role of enzymes in homeostasis. VIII. Inhibition of the activity of glycolytic enzymes by free fatty acids J. Biol. Chem. 243: 1096.
49. Goodman, A. D., R. E. Fuisz, and G. F. Cahill, Jr. 1966. Renal gluconeogenesis in acidosis, alkalosis, and potassium deficiency: its possible role in regulation of renal ammonia production. J. Clin. Invest. 45: 612.

50. Goorno, W. E., F. C. Rector, Jr., and D. W. Seldin. 1967. Relation of renal gluconeogenesis to ammonia production in the dog and rat. Amer. J. Physiol. 213: 969.

51. Churchill, P. C., and R. L. Malvin. 1970. Relation of renal gluconeogenesis to ammonia production in the dog. Amer. J. Physiol. 218: 241.

52. Lemieux, G., and G. E. Plante. 1968. The effect of starvation in the normal dog including the dalmatian coach hound. Metab. Clin. Exp. 17: 620 . 